\title{
Big-eged bugs Geocoris: Diets research and potential of use in prevention of a number of insect pests in Vietnam
}

\author{
Nguyen Ngoc Bao Chau ${ }^{1 *}$, Le Thuy To Nhu ${ }^{1}$ \\ ${ }^{1}$ Ho Chi Minh City Open University, Vietnam \\ *Corresponding author: chau.nnb@ou.edu.vn
}

\begin{tabular}{ll}
\multicolumn{1}{c}{ ARTICLE INFO } & \multicolumn{1}{c}{ ABSTRACT } \\
\hline $\begin{array}{l}\text { DOI:10.46223/HCMCOUJS. } \\
\text { tech.en.9.1.353.2019 }\end{array}$ & $\begin{array}{l}\text { Big-eyed bugs Geocoris spp. (Lygaeidae, Hemiptera) are } \\
\text { small insects that are found in many parts of the world. They are } \\
\text { beneficial because they eat a multitude of insect pests in } \\
\text { agriculture. Big-eyed bugs Geocoris spp. are insects that receive } \\
\text { research attention in Florida and elsewhere because of the benefits } \\
\text { that these species give to plants (Med, 2001). Big-eyed bugs }\end{array}$ \\
Received: April 16 $16^{\text {th }}, 2019$ & $\begin{array}{l}\text { reproduce many generations in a year on weeds, perennial crops, } \\
\text { bushes. In spring the female big-eyed bugs start laying eggs on the } \\
\text { bevised: May } 20^{\text {th }}, 2019\end{array}$ \\
Accepted: May $21^{\text {st }}, 2019$ & $\begin{array}{l}\text { the role of predator Geocoris spp. in the ecosystem will provide } \\
\text { an alternative method in sustainable agriculture development. In } \\
\text { this short review, we discuss some convenient diets for the } \\
\text { Keywords: } \\
\text { big-eyed bugs, Geocoris } \\
\text { spp., insect pests, predator }\end{array}$ \\
\hline
\end{tabular}

\section{Introduction}

Big-eyed bugs Geocoris spp. in the order Hemiptera are a small insect that is found in many parts of the world. Geocoris spp. distributed in regions of the US such as Texas, Colorado, California, Hawaii, and other places such as southern Canada, Panama, Guatemala. Big-eyed bugs Geocoris spp. have about 25 species found in the US and Canada.

Geocoris punctipes appear throughout Florida and many other places: western New Jersey, southern Indiana, southern Colorado, southwest Texas, Arizona, California and Mexico. Geocoris punctipes are the most common species on cotton plants, living in gardens, lawns, agricultural crops. In addition, Geocoris punctipes are also found in bonsai gardens, vegetable gardens and strawberry greenhouse systems (Med, 2001).

The Geocoris bullatus and Geocoris uliginosus species are widely distributed in the United States and Canada. They are beneficial because they eat a multitude of insect pests in agriculture such as thrips, small Lepidopteran larvae, whitefly larvae, mites, etc. Recently, Liu and Zeng (2014) reported the influence of artificial diet versus live prey on the functional response of $G$. pallidipennis to understand the interaction between nutritional history and predation. In addition, a study by Yokoyama (1980) indicates that Geocoris pallens was successfully reared on a diet of sunflower seeds and nymphs of the large milkweed bug 
Oncopeltus fasciatus (Dallas). Geocoris punctipes nymphs and adults successfully attack and suck dry Heliothis virescens larvae of various sizes (Chiravathanapong \& Pitre, 1980).

With the aim of developing sustainable and safe agriculture, a series of products have been researched and produced: fertilizers, bio-pesticides, pest-resistant plants, ... At the same time, the use of natural enemies in pest control is a recent interest, such as Plutella xylostella to harm cruciferous vegetables and ladybirds Coccinella transversalis, to control of gray mealybug, Brevicoryne brassicae Linnaeus. Big-eyed bugs Geocoris spp. are also species of natural enemies that have high pest control efficiency. Knowledge of a predator's diets is important for the development of effective rearing methods. However, no such studies have been reported for Geocoris spp. in Vietnam where conditions are likely to differ from other countries.

\section{Diets for mass rearing geocoris}

Nymph and adult big-eyed bugs can eat a variety of small-sized preys including aphids, red spiders, insect eggs, small nymphs, larvae, white beetles, and mite species, categorizing them as generalist predators. Big-eyed bugs kill their prey immediately, sucking them dry, and eat many prey individuals to complete their development (Figure 1). Sometimes lack of food they eat other carnivorous insects or plant tissue to survive but the ability to harm plants is negligible. They have great benefits for agricultural crops, ornamental plants and many other plants. In addition, many studies have demonstrated big-eyed bugs Geocoris spp. can be fed with artificial food in the laboratory and has the same effect in a natural condition (Table 1).

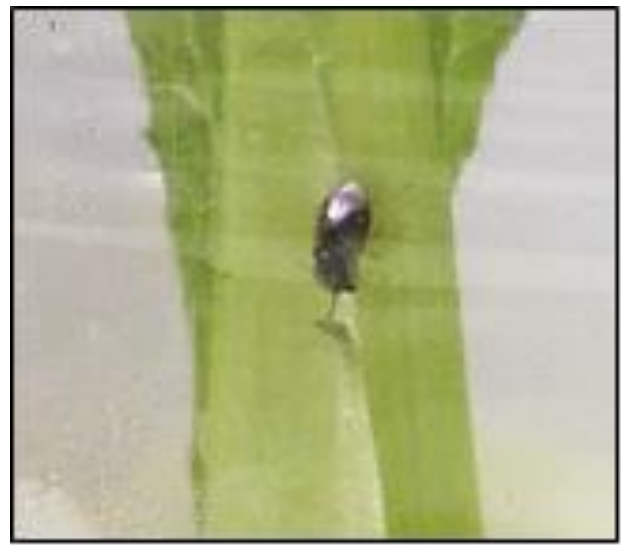

Figure 1. Big-eyed bug is sucking prey (Photo by: A. Q. P. Nguyen, 2018)

Geocoris spp. are primarily predaceous, although some species require plant food for optimal development. Supplementary feeding on plant material allows limited survival of $G$. punctipes when only poor quality prey or no prey are available (Eubanks \& Denno, 1999). The eggs of Ephestia kuehniella Zeller (Lepidoptera; Pyralidae) are used as the major food source for mass rearing Geocoris varius (Uhler) (Hemiptera: Geocoridae) resulting in high production costs of G. varius (Kiyoaki \& Nomura, 2013). On the other hand, G. punctipes, have been reared for more than 6 years (60 continuous generations) on meat products and eggs consist of ingredients that have a high moisture content. In addition, the occurrence of Geocoris ochropterus amongst crop pests as well as on fallow weeds can be understood as a part of 
predator-weed-crop interaction, the dietary influence of vegetative food on the biology of some species of Geocoris have been studied by Tamaki and Weeks (1972), Naranjo and Stimac (1985). Based on the findings of these authors, a combination diet of ant pupae as animal food and weed (twigs) as vegetative food was made to rear Geocoris. In an ant pupal diet, high carbohydrate, intermediate protein and fewer lipid levels supported a quick development and high fecundity in G. ochropterus. However, Cohen (1995) documented that higher protein, intermediate lipid, and low carbohydrate contents in an artificial diet was ideal for mass culture of Geocoris punctipes (Say). Cohen (1989) explained that lower ingestion efficiency on ant pupae (39.20\%) of G. ochropterus as compared to that of G. punctipes (65\%) on aphids may be due to a greater amount of non-consumable chitin of ant pupae.

Lepidopteran eggs have been researched on the development and survival of Geocoris lubra. Eggs of Anagasta kuehniella (Zeller) were also found suitable for the rearing of $G$. punctipes (Calixto, Bueno, Montes, \& Van Lenteren, 2014). Sitotroga cerealella eggs can be effectively utilized for the mass-rearing of G. ochropterus. Diet of Helicoverpa armigera (Hubner) eggs was successful in the development and survival of Geocoris lubra Kirkaldy from egg to adult rather than A. gossypii at $27^{\circ} \mathrm{C}$. Helicoverpa zea (Boddie) and the mirid, Lygus Hesperus (Knight), provide a high-quality diet for the development and survival of G. punctipes when a water source is also present (Lopez, Ridgway, \& Pinnell, 1976). In contrast, pea aphids (Acyrthosiphum pisum Harris) were a poor quality diet for G. punctipes (Eubanks \& Denno, 1999, 2000).

\section{Table 1}

List of some diets for rearing Geocoris spp.

\begin{tabular}{|l|l|l|}
\hline \multicolumn{1}{|c|}{ Geocoris species } & \multicolumn{1}{|c|}{ Diets } & \multicolumn{1}{c|}{ Reference } \\
\hline G. lubra & $\begin{array}{l}\text { Helicoverpa armigera (Hubner) eggs, } \\
\text { aphids (Aphis gossypii Glover) }\end{array}$ & $\begin{array}{l}\text { Mansfield, Scholz, } \\
\text { Armitage, and Johnson } \\
\text { (2007) }\end{array}$ \\
\hline G. punctipes & $\begin{array}{l}\text { Helicoverpa zea, Lygus hesperus, Eggs } \\
\text { of Anagasta kuehniella (Zeller), Aphids, } \\
\text { Whitefly Bemisia tabaci (Genn.), } \\
\text { meat products and eggs }\end{array}$ & $\begin{array}{l}\text { Eubanks and Denno (1999, } \\
\text { 2000); Calixto et al. (2014); } \\
\text { Cohen and Byrne (1992) }\end{array}$ \\
\hline G. ochropterus & $\begin{array}{l}\text { Sitotroga cerealella eggs, ant pupal } \\
\text { G. varius }\end{array}$ & $\begin{array}{l}\text { Tamaki and Weeks (1972); } \\
\text { Naranjo and Stimac (1985) }\end{array}$ \\
\hline G. pallidipennis & and ground pork & Kiyoaki and Nomura (2013) \\
\hline
\end{tabular}

Source: The researcher's data analysis

Liu and Zeng (2014) compared the functional response curve of both the nymphs and the adult female of Geocoris pallidipennis when fed to natural prey (M. persicae) and an 
artificial diet (included liver, yeast, chicken eggs and sugar) and the results showed that the functional response curve of both the nymphs and the adult female of G. pallidipennis to $M$. persicae reflected similar trends on both nutritional histories and confirmed the type II response (Figure 2). Adult female G. pallidipennis reared on either $M$. persicae or artificial diet produced a significantly better performance than the juvenile stages tested, and displayed high rates of predation.
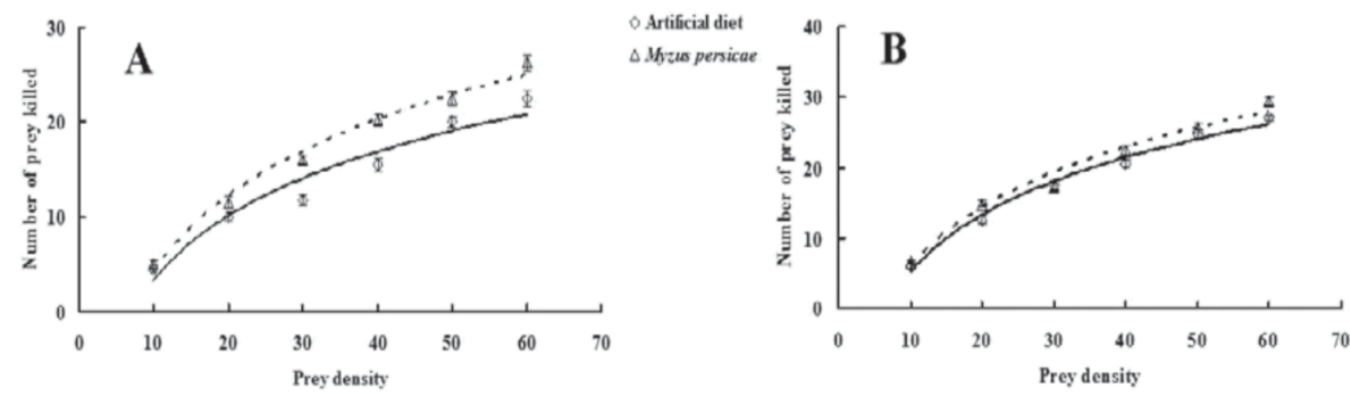

0 Artificial diet
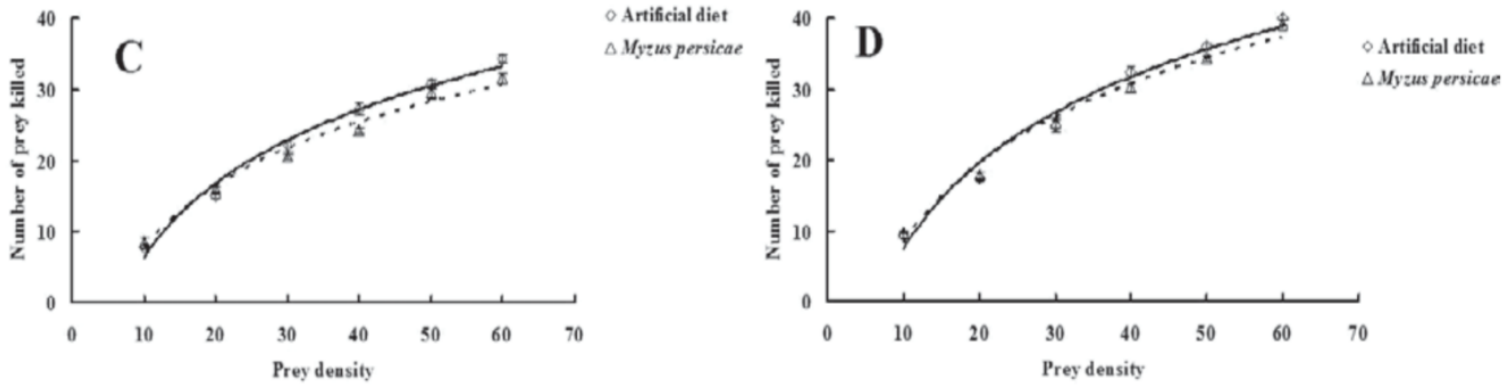

Figure 2. Functional response of $G$. pallidipennis from different nutritional history to $M$. persicae over $24 \mathrm{~h}$, data are presented as mean number $\pm \mathrm{SE}$ and predicted lines are fitted using the random predator equation. A-The third instar G. pallidipennis, B-the fourth instar $G$. pallidipennis, C-the fifth instar G. pallidipennis and D-the female G. pallidipennis (Liu \& Zeng, 2014)

Scientists have demonstrated that Geocoris reared on artificial diets are able to kill an equivalent amount of prey as those fed on natural prey or moth eggs such as Corcyra cehalonica eggs (Bonte, Samih, \& De Clercq, 2010; Hagler \& Cohen, 1991). Cohen (2000) also demonstrated that domesticated predators and their feral counterparts show similar characteristics of prey selection, metabolic efficiencies and digestive abilities.

\section{Research about big-eyed bugs and potential applications in Vietnam}

The selection of prey, feeding behavior, fertility and culture method as well as the reproductive parameters of big-eyed bugs with different physical conditions play an important role for successful breeding of natural enemies. Some species have been studied recently such as Geocoris punctipes (Say) (Ruberson, Yeargan, \& Newton, 2001), Geocoris lubra (Mansfield et al., 2007), are distributed in temperate regions; but there are no scientific parameters for Geocoris ochropterus in Vietnam, which was recorded in Madras, India (Kumar \& Ananthakrishnan, 1985) and is native to Vietnam by Cao and Dang (2011). 
According to Hagler and Cohen (1991), big-eyed bugs Geocoris spp. have the potential for effective biological control. As listed in table 1, Geocoris spp. have widened diets during their life. Both adults and nymphs can eat dozens of prey each day. In Arkansas, Geocoris punctipes and Geocoris uliginosus are one of the most important and effective predatory insects on cotton from June to September, big-eyed bugs also eat aphids, eggs and larvae of cotton insect pests (Bell \& Whitcomb, 1964). In addition, Lingren, Ridgway, and Jones (1968) noted that nymph big-eyed bugs eat an average of 47 spiders and adult big-eyed bugs eat about 83 red spiders each day. Research shows that the nymph stage can eat 1600 spiders to develop until becomes adult.

In Viet Nam, Geocoris spp. are found in many places such as Ninh Thuan, Can Tho provinces and $\mathrm{Cu} \mathrm{Chi}$ (Ho Chi Minh city) on okra, eggplant, pepper, and Vietnamese wax gourd (Benincasa hispida), etc. They are considered an important natural enemy to control insect pests in the country (C. N. B. Nguyen, Phan, \& Maeto, 2017, unpublished data). Under laboratory condition, Geocoris spp. female lay from 43,77 to 77 eggs at $29,75^{\circ} \mathrm{C}, 70,7 \% \mathrm{RH}, 27^{\circ} \mathrm{C}, 80 \%$ RH respectively. Adult preyed upon 232,4 leafhopper Amrasca devastans Distant (C. V. Nguyen, 2012). In addition, Geocoris spp. were also found on tea plantations at very low population density (Pham, 2013). We have attempted to multiply the G. ochropterus population in the laboratory and to study its biology, life table and feeding potential to meet the predator requirement for large-scale releases by developing an inexpensive and simple mass-rearing system.

Mass rearing of $G$. ochropterus on any convenient diet is essential for successful biological control programs. C. N. B. Nguyen et al. (2017) have examined the development and reproduction of $G$. ochropterus fed on three kinds of convenient diets: ant pupae Oecophylla smaragdina (AP), Bombyx mori pupae (BM), and adult aphids Aphis gossypii (A) as control. Results indicated that there was no significant difference in the body length, head width, and forewing length of grown-up G. ochropterus compared to control, except for BS in which the female body length and male forewing length was smaller. Significant differences were observed in adult weight (mg) of females fed on BS diet. There was no significant difference in development time (days) from the first to five larval instars of G. ochropterus among the treatments. Besides, some diets affected the total number of eggs laid; the bugs fed on AP produced the highest total number of eggs $(68.63 \pm 11.04$, mean $\pm \mathrm{SD}, \mathrm{n}=8)$, which was significantly different from the control $(\mathrm{P}<0,01)$. Finally, diets did not influence egg hatching percentage and survival rate of $G$. ochropterus. Our study suggests that all of the ant pupae Oecophylla smaragdina (AP) and Bombyx mori pupae (BM) can be used for mass rearing of $G$. ochropterus (unpublished data).

\section{Conclusion}

Vietnam is an agricultural country, with up to $70 \%$ of the population working in this area. Therefore, agricultural production plays a very important role in the national economy. Because of that, the application of researches on inoculants and species of natural enemies to control insects that cause harm to plants is essential when aiming at large-scale agriculture with 
ensuring productivity and quality, as well as minimize the use of chemical pesticides, ensuring VietGap standards and towards sustainable agriculture.

\section{References}

Bell, K. O., \& Whitcom, W. R. (1964). Field study on egg predators of the bollworm Heliothis zea (Boddie). Florida Entomologist, 47(4), 171-180.

Bonte, M., Samih, M. A., \& De Clercq, P. (2010). Development and reproduction of Adalia bipunctata on factitious and artificial foods. Biocontrol, 55, 485-491.

Calixto, A. M., Bueno, V. H. P., Montes, F. C., \& Van Lenteren, J. C. (2014). Development and thermal requirements of Nearctic predator Geocoris punctipes (Hemiptera: Geocordae) reared at constant and alternating temperature and fed on Anagasta kuehniella (Lepidoptera: Pyralidae) eggs. European Journal of Entomology, 111(4), 521-528.

Cao, N. T. Q., \& Dang, K. D. (2011). Result of the survey of bugs (Insecta: Heteroptera) in Tay Nguyen. Proceeding of $4^{\text {th }}$ National Conference on Ecology and Biological Resources, 223-231.

Chiravathanapong, S. A. N., \& Pitre, H. N. (1980). Effects of Heliothis virescens larval size on predation by Geocoris punctipes. Florida Entomologist, 63, 146-151.

Cohen, A. C. (1995). Extra-oral digestion in predaceous terrestrial arthropoda. Annual Review of Entomology, 40, 85-103.

Cohen, A. C. (1989). Ingestion efficiency and protein consumption by a heteropteran predator. Annals of the Entomological Society of America, 82, 495-499.

Cohen, A. C. (2000). Feeding fitness and quality of domesticated and feral predators: Effects of long-term rearing on artificial diet. Biological Control, 17, 50-54.

Cohen, A. C., \& Byrne, D. N. (1992). Geocoris punctipes as a predator of Bemisia tabaci: A laboratory evaluation. Entomologia Experimentalis et Applicata, 64, 195-202.

Crocker, R. L., \& Whitcomb, W. H. (1980). Feeding niches of the big-eyed bugs G. bullatus, G. punctipes, and G. uliginosus (Hemiptera: Lygaeidae: Geocorine). Environmental Entomology, 9(5), 508-513.

Eubanks, M. D., \& Denno, R. F. (1999). The ecological con-sequences of variation in plants and prey for an omnivorous insect. Ecology, 80(4), 1253-1266.

Eubanks, M. D., Denno, R. F. (2000). Health food versus fast food: the effects of prey quality and mobility on prey selection by a generalist predator and indirect interactions among prey species. Ecological Entomology, 25, 140-146.

Hagler, J. R., \& Cohen, A. C. (1991). Prey selection by in vitro - and field reared Geocoris punctipes. Entomologia Experimentalis et Applicata, 59(3), 201-205.

Kapadia, M. N., \& Puri, S. N. (1991). Biology and comparative predation efficacy of three heteropteran species recorded as predators of Bemisia tabaci in Maharashtra. Entomophaga, 36(4), 555-559. 
Kiyoaki, I., \& Nomura, M. (2013). Development and reproduction of Geocoris varius (Hemiptera: Geocoridae) on two types of artificial diet. Applied Entomology and Zoology, 48(3), 403-407.

Kumar, N. S., \& Ananthakrishnan, T. N. (1985). Geocoris ochropterus Fabr. as a predator of some thrips. Proceedings of the Indian National Science Academy, 2, 185-193.

Lingren, P. D., Ridgway, R. L., \& Jones, S. L. (1968). Consumption by several common arthropod predators of eggs and larvae of two Heliothis species that attack cotton. Annals of the Entomological Society of America, 61(3), 613-618.

Liu, F., \& Zeng, F. (2014). The influence of nutritional history on the functional response of Geocoris pallidipennis to its prey, Myzus persicae. Bulletin of Entomological Research, 104(6), 702-706.

Lopez, J. D., Jr., Ridgway, R. L., \& Pinnell, R. E. (1976). Comparative efficacy of four insect predators of bollworm and tobacco budworm. Environmental Entomology, 5(6), 11601164.

Mansfield, S., Scholz, B., Armitage, S., \& Johnson, M. L. (2007). Effects of diet, temperature and photoperiod on development and survival of the bigeyed bug. Geocoris lubra. BioControl, 52(1), 63-74.

Med, F. W. (2001). Bigeyed bugs, Geocoris spp. (Insecta: Hemiptera: Geocoridae) IFAS extension. Retrieved January 15, 2019, from http://entomology.ifas.ufl.edu/creatures

Naranjo, S. E., \& Stimac, J. L. (1985). Development, survival, and reproduction of Geocoris punctipes (Hemiptera: Lygaeidae): Effects of plant feeding on soybean and associated weeds. Environmental Entomology, 14(4), 523-530.

Nguyen, A. Q. P. (2018). Effects of photoperiod on the development and survival and prey consumption of the bigeyed bug Geocoris spp. (Lygaeidae, Hemiptera) (Bachelor's thesis). Ho Chi Minh City Open University, Vietnam.

Nguyen, C. N. B., Phan, Q. T. T., \& Maeto, K. (2017). Effects of convenient diets on development and reproduction of big-eyed bug, Geocoris ochopterus for mass rearing. Paper presented at the 5th International Entomophagous Insects Conference, Kyoto, Japan.

Nguyen, C. V. (2012). Study on natural enemies of leafhopper Amrasca devastans distant; biology of Big-eyed bugs Geocoris spp. (Master's thesis). Ha Noi University of Agriculture, Vietnam.

Pham, L. V. (2013). Species composition of arthropods on tea in Vietnam. Proceeding of the $5^{\text {th }}$ National Conference on Ecology and Biological Resources, 530-537.

Ruberson, J. R., Yeargan, K.V., \& Newton, B. L. (2001). Variation in diapause responses between geographic populations of the predator Geocoris punctipes (Heteroptera: Geocoridae). Annals of the Entomological Society of America, 94, 116-122. 
Schuman M. C., Danny, K., \& Ian, T. B. (2013). Ecological observations of native Geocoris pallens and G. punctipes population in the Great Basin Desert of Southwestern Utah. Psyche a Journal of Entomology, 2013, 1-11. doi:10.1155/2013/465108

Tamaki, G., \& Weeks, R. E. (1972). Biology and ecology of two predators, G. pallens Stal and G. bullatus (Say). Bulletin of the U.S. Department of Agriculture, 1446, 1-46.

Yokoyama, Y. V. (1980). Method for rearing Geocoris pallens (Hemiptera : Lygaeidae) a predator in California cotton. The Canadian Entomologist, 112, 1-4. 